\title{
Ecological sustainability of smallholder dairy farm with Leisa pattern
}

\author{
N. S. Asminaya ${ }^{1,2, *}$, B. P. Purwanto ${ }^{3}$, N. Nahrowi ${ }^{4}$, W. A. Ridwan ${ }^{3}$ and A. Atabany ${ }^{4}$ \\ ${ }^{1}$ Graduate School, Faculty of Animal Science, Bogor Agricultural University, \\ Jl. Raya Dramaga, Kampus IPB Dramaga Bogor 16680 - Indonesia \\ ${ }^{2}$ Permanent Address: Faculty of Animal Science, Halu Oleo University, \\ Jl. HEA Mokodompit, Green Campus, Kendari 93132 - Indonesia \\ ${ }^{3}$ Vocational College, Bogor Agricultural University, \\ Jl. Kumbang No. 14 Cilibende, Bogor 16151 - Indonesia \\ ${ }^{4}$ Faculty of Animal Science, Bogor Agricultural University, \\ Jl. Agatis, Dramaga Campus, Bogor 16680 - Indonesia, \\ *Corresponding E-mail: nurshantyasminaya_uho@yahoo.com
}

Received March 10, 2018; Accepted September 10, 2018

\begin{abstract}
ABSTRAK
Penelitian ini bertujuan untuk mengetahui status keberlanjutan usaha peternakan sapi perah rakyat yang menerapkan pola Low Exeternal Input Sustainable Agriculture (LEISA) dan merumuskan model yang berkelanjutan. Penelitian dilakukan pada 8 peternakan sapi perah rakyat di Kawasan Usaha Peternakan (KUNAK) Kabupaten Bogor dengan kriteria: rataan kepemilikan ternak 11 ekor, menanam rumput gajah di sekitar kandang, mengalirkan kotoran ternak pada lahan kebun rumput, tidak menggunakan pupuk kimia, luas lahan $4250 \mathrm{~m}^{2}$. Analisis data dilakukan dengan cara: 1) penentuan atribut, 2) penentuan skala ordinal berdasarkan kriteria keberlanjutan, 3) analisis data (software Rap Dairy), 4) mengkaji nilai indeks dan status keberlanjutan, 5) mengkaji atribut sensitif (analisis Leverage) dan 6) validasi model (analisis Monte Carlo dan Square Correlation (SQR)). Atribut dan skala ordinal pada keberlanjutan ekologi adalah kepadatan ternak, kapasitas tampung, kondisi air, drainase kandang, kesuburan tanah, topografi, curah hujan, kelembaban, suhu dan ketinggian tempat. Analisis Rap Dairy menunjukkan bahwa usaha peternakan sapi perah rakyat pola LEISA secara ekologis cukup berkelanjutan dengan indeks 57.95. Indeks dapat ditingkatkan menjadi 88.39 (berkelanjutan) melalui simulasi model dengan memperhatikan atribut sensitif. Analisis Leverage menunjukkan bahwa topografi, kepadatan ternak, kapasitas tampung, ketersediaan air merupakan atribut sensitif. Analisis Monte Carlo dan SQR menunjukkan bahwa model dapat menjelaskan data dengan baik.
\end{abstract}

Kata kunci: leisa, berkelanjutan, sapi perah, rapdairy, ekologi

\begin{abstract}
This study was conducted to determine the sustainability status of smallholder dairy farms applying Low External Input Sustainable Agriculture (LEISA) pattern, and to formulate sustainable model. Eight smallholder dairy farms located in livestock business area $(K U N A K)$ were purposive selected with criteria was they had 11 heads dairy cows, planted an elephant grass, dispose the manure to grassland, did not use chemicals fertilizer, $4250 \mathrm{~m}^{2}$ land area of dairy farming. Data were analyzed by: 1) attribute determination, 2) ordinal scale determination based on sustainability criteria; 3 ) data analysis (Rap Dairy software); 4) assessment of index and sustainability status; 5) review sensitive attributes (leverage
\end{abstract}


analysis) and 6) validation model (Monte Carlo and Square Correlation (SQR) analysis). Attributes and ordinal scale on ecological sustainability were density of dairy cow, carrying capacity, supply water, drainage cages, soil fertility, topography, rainfall, humidity, temperature and altitude. Results of Rap Dairy analysis showed that smallholder dairy farms who apply LEISA pattern ecologically was quite sustainable with index of 57.95. The index could be increased to 88.39 (sustainable) through model simulation with respect to sensitive attributes. The results of Leverage analysis showed that topography, density of dairy cow, carrying capacity, supply water availability were sensitive attributes. Analysis Monte Carlo and SQR showed that model could explain data well.

Keywords: leisa, sustainability, dairy, rap dairy, ecology

\section{INTRODUCTION}

Sustainable agriculture is a farming system which developed ecologically harmless, economically profitable, socially in accordance with the local culture with a holistic approach (Horrigan et al., 2002). Sustainable agriculture system in general sense is ecologically oriented, while in specific sense is optimizing local agricultural resources without using of external inputs. There were several terms used in sustainable agriculture system: Low External Input Agriculture (LEIA) (Jager et al., 2001); Low External Input Sustainable Agriculture (LEISA) (Diwyanto et al., 2001; Ibeawuchi et al., 2015); Low External Input Strategies (Yengoh and Svensson, 2008); Sustainable Agriculture (Kassie and Zikhali, 2009); Low External Input Technology Agriculture (LEITA) and High External Input Technology Agriculture (HEITA) (Anyanwu, 2011); Ecofarming (Salendu and Elly, 2011); Low Input Sustainable Agriculture (LISA), (Najafabadi et al., 2012); or Organic Agriculture (Augustine et al., 2013).

Mustikarini et al. (2010) stated that LEISA is an agro ecosystem designed to maximize the recycling process, minimize the use of external inputs, and provide income periodically so that farmers can meet the needs of life continuously. External inputs were only used to supplement less elements in the ecosystem and exploit the use of genetic resources complementary and synergistic thereby minimizing environmental damage. LEISA is a concept of combining agriculture, livestock and fisheries sustainable that suppress the use of external inputs to obtain an efficient, eco-friendly, crisis-resistant and competitive farming system. Ibeawuchi et al. (2015) stated that LEISA generally applied by small-scale farmers with the use of technology, labor, capital and low production materials.

Agriculture as a production systems were produce pollution, causes of land and environmental degradation, marginal land expansion and maritime outflow (downstream) (Salendu and Elly, 2011). Thus, if farming system and livestock did not processed in a sustainable way, it will lead to degradation of natural resources and the environment.

In Indonesia, smallholder dairy farms were traditionally managed and tend to apply the LEISA pattern to reduce the use of production costs. Similarly in Bogor's Livestock Business Area (Kawasan Usaha Peternakan, KUNAK), the application of LEISA pattern was done by rearing the cows integrated with elephant grass in order to reduce cost of feed purchasing. In the rainy season the use of feed in the form of agricultural waste (rice straw) as additional feed is quite low (Asminaya et al., 2017). The disposal of dairy cow manure and wastewater disposal were flown to the grasslands to support the availability of soil nutrients for elephant grass growth and reduce the use of chemical fertilizers.

The traditional management applied in $K U N A K$ in line with zero waste principle. Zero waste was an integration technology to gain a double advantage: 1) increase productivity, 2) overcoming environmental pollution, 3) cheap, increase fertility and sustainability of the land, and 4) increase farm income and efficiency (Galib, 2008). Zero waste agricultural technology can be developed with the support of human resources at the productive age and the level of education (Sunanto and Nasrullah, 2012). This pattern was done to reduce the use of high production cost so that the maintenance system is still far from the standard of Good Farm Practice (GFP). Most dairy farms did not pay attention to general maintenance management, ignoring animal health control, veterinary and animal conditions, feeding and drinking water, the environment and infrastructure and also handling of products. Then will be implication to the low 
dairy cow productivity.

In this regards, it is necessary to assess the most sensitive attributes, statuses and index ecological sustainability of dairy farms in the rainy season. The results of this study can be used as a foundation in the development policy of dairy farm ecologically to increase dairy cow productivity.

\section{MATERIALS AND METHODS}

\section{Time and Place}

This research was conducted during rainy season (January-March 2015 and NovemberDecember 2015). The data were collected from dairy cattle farms those applied LEISA pattern with land ownership of $4250 \mathrm{~m}^{2}$ in $K U N A K$, Cibungbulang, Bogor.

\section{Collecting Data}

Data were collected by observations and interviews with dairy farmers, government official and academic/expert. The collected data were density of dairy cow, carrying capacity, supply water, drainage cage, soil fertility, topography, rainfall, humidity, temperature and altitude.

\section{Sustainability Dairy Farm Analysis}

Analysis of sustainable dairy farm was carried out by multidimensional scaling approach (MDS) (Yusuf et al., 2016) with Rap Dairy (Rapid Appraisal of Dairy) software. Rap Dairy were modification from Rapfish (Rapid Appraisal of Fisheries) to determine status and index sustainability of the smallholder dairy farms. (Pitcher and Preikshot, 2001). The stages of Rap Dairy analysis include:

1. Determination of ecological dimension attributes on smalholder dairy farms which apply LEISA pattern in KUNAK. Attributes include factors that affect sustainability of smallholder dairy farms.

2. Each attributes of ecological dimension were given an ordinal score from 0 (zero) to 9 (nine) which represents the lowest to highest stratum of assessment. Zero score was bad and nine score was good. The higher score will give the higher contribution to the sustainability of the smallholder dairy farm.

3. Analysis of attributes scores using Rap Dairy software

4. Assess the status and index sustainability of smallholder dairy farm which apply
LEISA pattern in $K U N A K$ according to Kavanagh and Pitcher (2004): Index score 0.00-24.99 (bad, unsustainable); 25.0049.00 (less sustainable); 50.00-74.99 (enough, quite sustainable); 75.00-100.00 (good, sustainable).

5. Sensitive attributes were assessed using Leverage analysis (Mulyana et al., 2011). Sensitivity analysis was performed to see attributes that play a strong role in determinee sustainability. Sensitivity analysis was done by look at the effect of Root Mean Square (RMS). The greater value of RMS changes due to the loss of an attributes, the greater role of attributes as a determinant of sustainability on smallholder dairy farm in KUNAK.

6. Evaluate the error rate score, score variation, data input error/missing data and high stress value were analyzed using Monte Carlo (Frimawaty et al., 2013).

\section{Validation Model}

Validation of the model was done by look at stress value, Square Correlation (SQR) and differences between Monte Carlo value and rap analysis. The value of stress or a lack of fit measurement was less than $25 \%$ or $\mathrm{S} \leq 0.25$ (Ratnaningtyas et al., 2016). The value of SQR or the result of goodness of fit approaches 100, indicate that the model can explain the data and each of attribute is sufficiently accurate and reliable (Cahya, 2016). Goodness of fit in MDS was intended to see the distance of estimated point and original point and to see how well the measurement was (Baroleh et al., 2016). Difference between Monte Carlo value and rap analysis are $<5 \%$ (Kavaragh and Pitcher, 2004).

\section{RESULTS AND DISCUSSIONS}

\section{Sustainability Status}

Rap Dairy analysis of ecological dimension on smallholder dairy farm during rainy season in $K U N A K$ was at position of 57.95 from index of 0 100 or in middle category (Figure 1). These sustainability index was lower than Erif Farm (76.21) and Cifa Farm in Cisarua (76.92) (Jaenudin et al., 2017). The result of leverage analysis showed that attribute $\geq 4$ was manure flow to the grassland, topography and rainfall (Figure 2). These attributes were an attribute that must be minimized in order to keep sustainability of ecological dimension on the operation of 


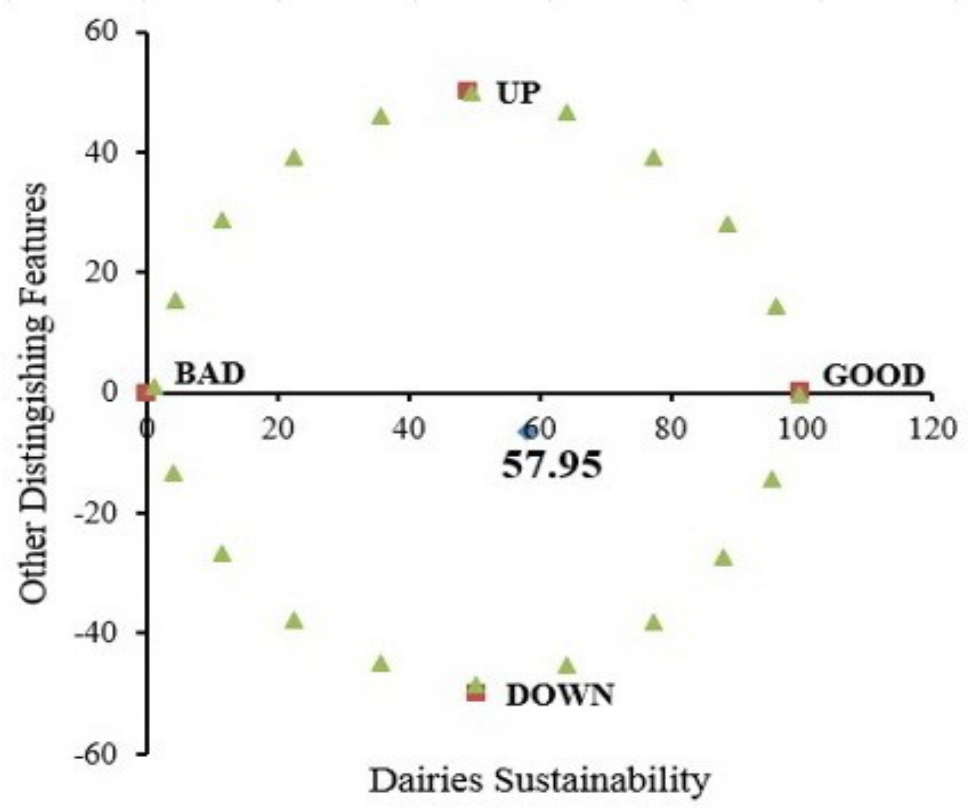

Figure 1. Rapdairy Ordiantion of Sustainablity Ecology on Smallholder Dairy Farm which Apply LEISA Pattern in KUNAK during Rainy Season.

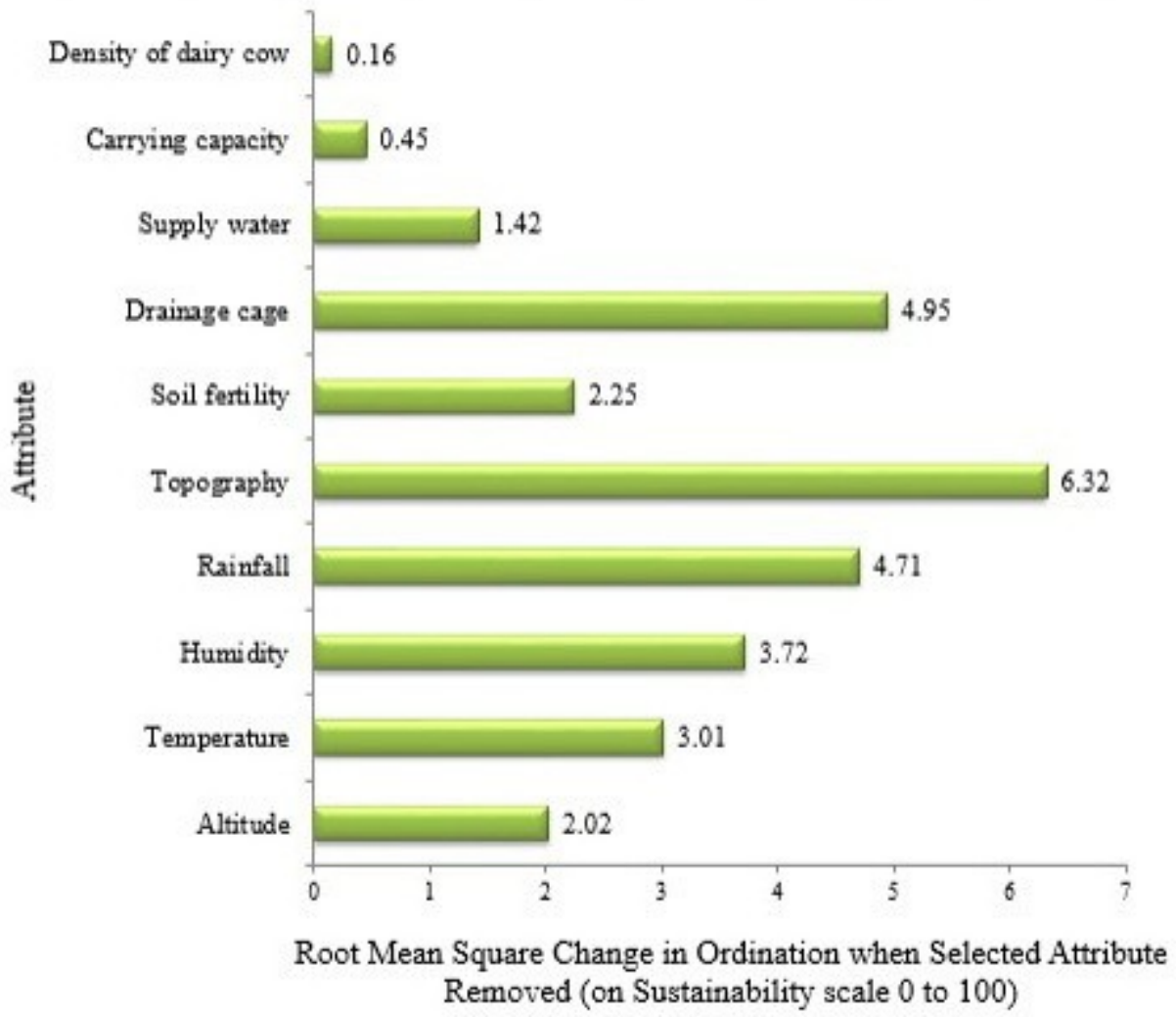

Figure 2. Leverage Analysis of Ecological Sustainability Smallholder Dairy Farm which Apply LEISA Pattern at $K U N A K$ during Rainy Season. 
smallholder dairy farms which apply LEISA pattern at KUNAK.

Manure flow to the grassland was closely related to the cleanliness of the animal housing, waste management and forage growth. The cleanliness of the animal housing closely related to dairy cow's health. The cleanliness of the animal housing will provide a comfort condition and healthy atmosphere for the cows to support optimal growth and productivity. Everitt et al. (2002) stated that housing hygiene, lactating cow conditions, equipments, dairyman greatly influenced the quality of produced milk and the number of milk bacteria. Kusnadi and Juarini (2007) stated that the number of milk bacteria (the total plate counts), milk fat and total solid were determinants of milk price in Indonesia.

Therefore, sanitation and control on feeding, equipments and milking process should be received special attention. Before milking process started, the cows should be cleaned at around their stomach and udder using warm water. Similarly, the housing and equipments also must be cleaned before milking. The cleanliness of housing will be in clean condition if the housing drainage is well managed, so that the waste management becomes more manageable. Minister of Agriculture regulation No. 100/Permentan/OT.140/7/2014 concerning Good Farming Guidance for Dairy Cow Breeding mentioned that every dairy cow farm must have a good drainage and sewerage, with floor's slope of 2-5 degrees, not slippery, not rough, easy to dry and resistant stamping and also use mat (carpet/mat) to keep the animal house clean and not inundated with water. Good management of animal house's drainage will also facilitate easy waste management (fesses/urine) for organic fertilizer or biogas.

Topography attributes also required attention since it greatly affects the position of the animal housing, the comfort of the cows, and the worker's activities for forages supply. Land with flat topography will make the cows farmers more comfort and more easyily to run farm's activities such as feeding, milking and feed and milk transportations. Suratman and Busyra (2006) showed that the best topography slopes for dairy farm was less than $15 \%$, if the slope more than $30 \%$ needed intensive land conservation. The growth of some forages species will be vulnerable under conditions of highlands more than $1200 \mathrm{~m}$ above sea level. Yani and Purwanto (2006) stated that the best topography for dairy farm was more than $800 \mathrm{~m}$ above the sea level.
Rainfall is attributes that have been fixed and cannot be modified by management activity. So, if we want to develop smallholder dairy farm which apply of LEISA pattern must pay consider to rainfall conditions since rainfall is microclimate which indirectly influence the productivity of dairy cows (Yani and Purwanto, 2006). According to Suratman and Busyra (2006), the suitable temperatures and humidity for optimum growth of forage and dairy cow production were $18-35^{\circ} \mathrm{C}$ and $60-90 \%$, respectively. The excessively dry rainfall (less than $400 \mathrm{~mm} / \mathrm{year}$ ) and drought conditions more than 8 months/years will slow up the growth of forages. The suitable temperatures and humidity for dairy cow production were $18.3^{\circ} \mathrm{C}$ and 55\%, respectively (Yani and Purwanto, 2006).

Leverage analysis were attributes those did not sensitive but influenced the sustainability of smallholder dairy farm. The attributes were the density of dairy cow, carrying capacity of land and supply of water. All of the attributes score must be increased so that the farmers could keep their dairy farm sustained. The attributes of dairy cow density will affect the availability of forage (Ajayi et al., 2005) and the feed fulfillment (Despal et al., 2011). The results showed that there has been over capacity of dairy cow at the smallholder dairy farm which apply LEISA pattern in KUNAK. This condition was caused by the wish of farmers to increase their income without taking account the availability of the forage. All respondent of this study kept the dairy cow almost twice than that of the number of dairy cows those should be retained. Based on the existing land conditions and the availability of forage, the density of dairy cow should be less than 7 animal units (AU); however they kept up to $11 \mathrm{AU}$. Thus, the availability of existing feeds did not able to meet dairy cow's need and the addition of external feeds (concentrate and forage) in limited quantities did not offer a good impact on the cow's productivity.

\section{Ecologically Sustainable Model of Smallholder Dairy Farm}

The analysis result of ecological dimension on the model showed that the smallholder dairy farm's sustainability which apply LEISA pattern could be sustain and had a 88.39 from index category 0-100 (Figure 3). The value was obtained by an improvement of ecological dimension. The result of leverage attribute 


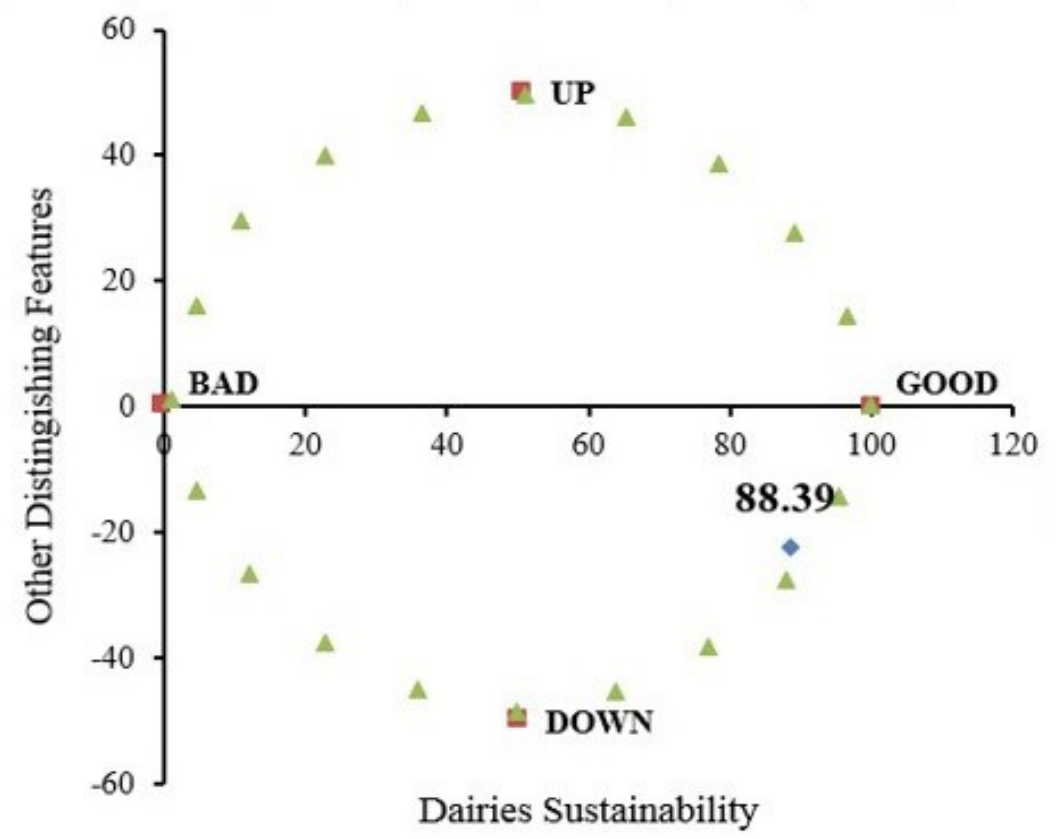

Figure 3. Rapdairy Ordiantion of Ecologically Sustainable Model of Smallholder Dairy Farm which Apply LEISA Pattern in KUNAK during Rainy Season.

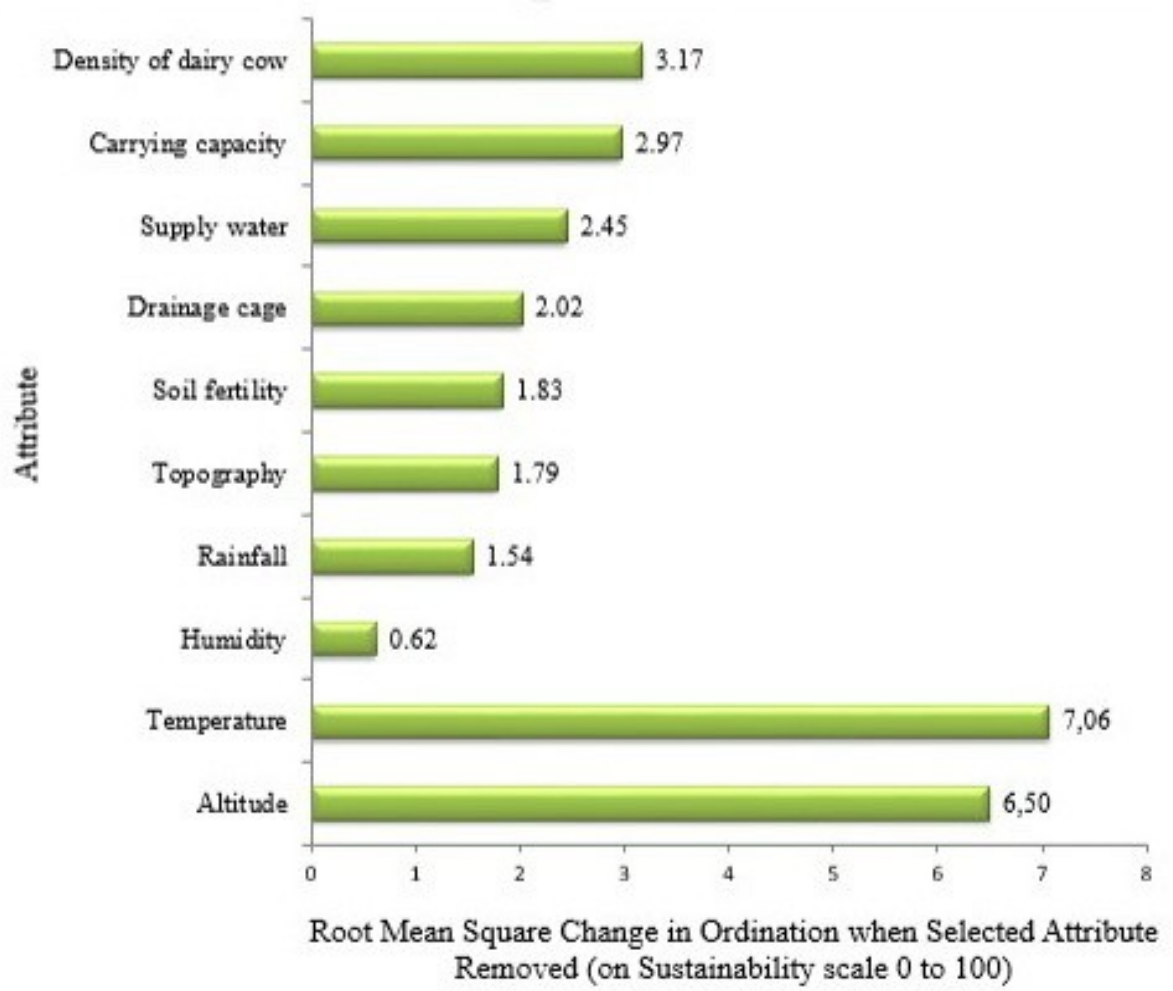

Figure 4. Leverage Analysis Model of Ecological Sustainability Smallholder Dairy Farm which Apply LEISA Pattern at KUNAK during Rainy Season 
analysis was shown in Figure 4.

Rap Dairy analysis results on the status of smallholder dairy farm sustainability which apply LEISA pattern at KUNAK indicated that there were some attributes that still need to be improved. The attributes need to be improved were density of dairy cow, the carrying capacity and supply of water so that status of smallholder dairy farm will be sustainable. The results showed that there has been excess capacity in the smallholder dairy farm which apply LEISA pattern in KUNAK. This can be seen from the number of dairy cows kept by the farmers (11 AU) more than the number should be maintained (7 AU). These conditions cause the availability of elephant grass is not sufficient for dairy cow needs and impact on the low productivity of dairy cow. Generally, the farmers keep the dairy cow to get big profit without considering the availability of feeding factor so that productivity becomes less optimal. In general, the production of elephant grass in the grassland is not able to meet the needs of the dairy cows. Elephant grass production at present is 194.95 ton/ha/season or equivalent to $2508.5 \mathrm{~kg} / \mathrm{m}^{2} / \mathrm{d}$. The production of elephant grass can accommodate dairy cow as much as $7.42 \mathrm{AU}$. The number of cattle kept by farmers are $11 \mathrm{AU}$, then the existing elephant grass production is not able to meet the needs of dairy cattle. In fact, to increase the productivity of dairy cattle required adequate amount of feed, available throughout the year and good quality.

Carrying capacity in dairy farm was closely related to animal feed (Ajayi et al., 2005), nutrient needs (Despal et al., 2011) and dairy cow density in the rainy season (Nugraha et al., 2013). The results showed that the existing land did not able to meet the needs of dairy cattle feed because the number of dairy cows were maintain exceeds the capacity that should be.

Therefore, if farmers want to increase dairy cow productivity and sustainability status of smallholder dairy farm which apply LEISA pattern, hence breeders should keep dairy cow according to the amount of capacity they should be. Breeders at $K U N A K$ should reduce the number of dairy cows their maintain to the number they should be breed according to carrying capacity. Reduce the number of dairy cow can be done based on selection of milk production. According to Karnaen and Arifin (2007), optimal milk production can be improved by improving the genetic quality by recording the cow identity, milk production, reproductive data, and animal health so that the selection program becomes directed. A dairy cow has several times lactation during life so that more lactation records will be more precise and accurate production capability. Such records may be used to estimate heritability and breeding of dairy cattle. Dairy cattle that have high heritability and breeding values can be used as a mother on the next generation. In addition, the carrying capacity and supply of water must also be considered. Carrying capacity were related to stocking rate of forage production and milk yield (Macdonald et al., 2008), enlarging of scale in dairy farming (Jaarsma et al., 2013) and scenarios of diets (Peters et al., 2016).

\section{Validation of Sustainability}

Validation of sustainability model of smallholder dairy farm which apply LEISA pattern at KUNAK was done by comparing the result of MDS calculation with Monte Carlo. The validation result on the model of sustainability of smallholder dairy farm which apply LEISA pattern in this research showed that the feasibility value of 0.128 MDS model was valid because the value is smaller than 0.25 . The value of Squared Correlation (RSQ) in this study was 0.957. It means the sustainability of smallholder dairy farm which applies LEISA pattern in KUNAK at level 84.76 was in agreement with the actual conditions.

\section{CONCLUSION}

The ecological sustainability status of smallholder dairy farm which applies LEISA pattern can be increased from less sustainable (57.95) to sustainable (88.39) through structuring on attributes (animal density, carrying capacity and water and forage availabilities).

\section{ACKNOWLEDGMENTS}

Special thanks to Chairman of farmers in Cibungbulang Smallholder Dairy Farm for technical support throughout this study. This study was funded by Direktorat Jenderal Pendidikan Tinggi through Beasiswa Pendidikan Pascasarjana (BPPS) tahun Anggaran 2015, grant no: 2604/E4.4/2012 and Faculty of Animal Science Universitas Halu Oleo through "Hibah Doktor Fakultas Peternakan UHO tahun 2015"

\section{REFERENCES}

Ajayi, D.A., J.A. Adeneye and F.J. Ajayi. 2005. 
Intake and nutrient utilization of West African dwarf goats fed mango (Mangifera indica), ficus (Ficus thionningii), gliricidia (Gliricidia sepium) foliages and concentrates as supplements to basal diet of guinea grass (Panicum maximum). World J. Agric. Sci. 1(2):184-189.

Anyanwu, S.O. 2011. Comparative analysis of economic efficiency between low and high external input technology agriculture in a harsh macroeconomic environment of Imo State, Nigeria. Int. J. Agric. Manag. Dev. 1(3):115-122.

Asminaya, N.S., B.P. Purwanto, Nahrowi, W.A. Ridwan and A. Atabany. 2017. Milk yield and nutrient adequacy of lactating dairy cow fed based on tofu waste, soybean hulls and straw. Int. J. Sci. Res. (IJSR). 6(7):951-956.

Augustine, A.J., G.E. Jokthan, I.C. Zarafi and M. Bivan. 2013. Optimizing opportunities for sustainable development through organic agriculture in Nigeria. J. Agric. Vet. Sci. 4(1):7-11.

Baroleh, M.S., A. Fahrudin, R. Dahuri, S.B. Susilo and D. Monintja. 2016. Miangas, the outermost small island of Indonesia. Int. J. Sci.: Basic App. Res. 26(1):12-25.

Cahya, D.L. 2016. Analysis of urban agriculture sustainability in Metropolitan Jakarta (case studi : urban agriculture in Duri Kosambi). Procedia - Soc. Behav. Sci. 227(2016):95100.

Despal, D., I.G. Permana, S.N. Safarina and A.J. Tatra. 2011. Penggunaan berbagai sumber karbohidrat terlarut air untuk meningkatkan kualitas silase daun rami. Media Peternakan. 34(1):69-76.

Diwyanto, K., B.R. Prawiradiputra and D. Lubis. 2001. Integrasi tanaman-ternak dalam pengembangan agribisnis yang berdaya saing, berkelanjutan dan berkerakyatan. Wartazoa. 12(1):17-26.

Everitt, B., T. Ekman and M. Gyllenward. 2002. Monitoring milk quality and udder health in Swedish AMS Herds. Proc. of the 1st North American Conference on Robotic Milking. P.72

[FAO] Food and Agriculture Organization of the United Nations and IDF (International Dairy Federation). 2011. Guide to Good Dairy Farming Practice. FAO Animal Production and Health \& Food and Agriculture. Organization of the United Nations and International Dairy Federation. Rome
Frimawati, E., A. Basukriadi, J.A. Syamsu and T.E.B Soesilo. 2013. Sustainability of rice farming based on eco-farming to face food security and climate change : case study in Jambi Province, Indonesia. Procedia Env. Sci.. 17(2013):53-59.

Galib, R. 2008. Pemanfaatan pelepah dan solid kelapa sawit sebagai pakan sapi, di lahan kering Kalimantan Selatan. Seminar Optimalisasi Hasil Samping Perkebunan Kelapa Sawit dan Industri Olahannya sebagai Pakan Ternak. Litbang Penelitian. Departemen Pertanian, Jakarta. P 158-161.

Horrigan, L., R.S. Lawrence and P. Walker. 2002. How sustainable agriculture can address the environmental and human health harms of industrial agriculture. Env. Health Perspective. 110(5):445-455.

Ibeawuchi, I.I., J.C. Obiefuna and U.P. Iwuanyanwu. 2015. Low external input agricultural farming system for the increase in productivity of resources poor farmers. J. Biol. Agric. Health. 5(2):109-116.

Jaarsma, R., T. Hermans, W. Rienks and J. de Vries. 2013. Enlarging of scale in dairy farming: Consequences for farm-bound traffic flows in the countryside. NJAS Wageningen J. Life Sci. P 67-75

Jaenudin, D., A.A. Amin, M.A. Setiadi, H. Sumarno and S. Rahayu. 2017. Sustainability status of dairy farms in Bogor District Area, Indonesia. Int. J. Sci. : Basic App. Res. (IJSBAR). 34(2):34-53.

Jager, A.D., D. Onduru, M.S.W. Van, J. Vlaming and G.N. Gachini. 2001. Assessing sustainability of low external input farm management systems with the nutrient monitoring approach: a case study in Kenya. Agri. Systems. P 69:99-118.

Karnaen and J. Arifin. 2007. Korelasi nilai pemuliaan produksi susu sapi perah berdasarkan test day laktasi 1, laktasi 2, laktasi 3, dengan gabungannya. Anim. Prod. 11(2):135-142.

Kavanagh, P and T.J. Pitcher. 2004. Implementing Microsoft Eexcel Software for Rapfish : A Technique for the Rapid Appraisal of Fisheries Status. Fisheries Centre research Reports. 12 (2) Fisheries Centre. University of British Colombia. Canada.

Kessie, M and P. Zikhali. 2009. Sustainable Land Management and Agricultural Practice in Africa: Bridging the Gap between Research and Farmers. Gothenburg, Sweden. 
Kusnadi, U and E. Juarini. 2007. Optimalisasi pendapatan usaha pemeliharaan sapi perah dalam upaya peningkatan produksi susu nasional. Wartazoa. 17(1):21-28.

Macdonald, K.A., J.W. Penno, J.A.S. Lancaster and J.R. Roche. 2008. Effect of stocking rate on pasture production, milk production, and reproduction of dairy cows in pasture-based systems. J. Dairy Sci. 91:2151-2163

Mulyana, R., J. Haluan, M.S. Baskoro and S.H. Wisudo. 2011. Analisis multidimensional untuk pengelolaan perizinan perikanan yang berkelanjutan : studi kasus WPP Laut Arafura. J. Teknologi Perikanan. 2(1):71-79.

Mustikarini, E.D., T. Lestari and R. Santi. 2010. Penerapan paket teknologi LEISA pada lahan pasca penambangan timah di Kecamatan Mendo Barat, Bangka. Enviagro, J. Pertanian dan Lingkungan. 3(1):22-29.

Najafabadi, M.O., K. Khedri and F. Lashgarara. 2012. Requirements of low input sustainable agricultural implementation: a factor analysis of expert's perspective. J. Agric. Biol. Sci. 7(8):583-585.

Nugraha, B.D., E. Handayanta and E.T. Rahayu. 2013. Analisis daya tampung (carrying capacity) ternak ruminansia pada musim penghujan di daerah pertanian lahan kering Kecamatan Semin Kabupaten Gunungkidul. Tropical Animal Husbandry. 2(1):34-40

[PERMENTAN] Peraturan Menteri Pertanian. 2014. No 100/Permentan/OT.140/7/2014 tentang Pedoman Pembibitan Sapi Perah yang Baik. http://bibit.ditjenpkh.pertanian. go.id/regulasi/pedoman-pembibitan-sapi-perah -yang-baik.[Downloaded 4 July 2018].

Peters, C.J., J. Picardy, A.F. Darrouzet-Nardi, J.L. Wilkins, T.S. Griffin and G.W. Fick. 2016. Carrying capacity of U.S. agricultural land: Ten diet scenarios. Elem. Sci. Anth. 4:1-15.

Pitcher, T.J. and B.D. Preikshot. 2001. Rapfish: a rapid appraisal technique to evaluate the sustainability status of fisheries research. Fisheries Res. 49:225-270.
Ratnaningtyas, N.A., W.F. Ma'ruf, T.W. Agustini, J. Hutabarat and S. Anggoro. 2016. Prospect and adversity the downstream of "softbone milkfish" in Semarang City, Indonesia. Aquatic Procedia. 7(2016):166-176.

Salendu, A.H.S and F.H. Elly. 2011. Model integrasi kelapa-ternak sapi sebagai suatu pendekatan ecofarming di Sulawesi Utara. Prosiding Seminar Nasional Strategi Pembangunan Peternakan Masa Depan Melalui Pendekatan Eco-Farming. Manado, 13 September 2011. P 122-130.

Sunarto and Nasrullah. 2012. Kajian model pertanian zero waste dengan pendekatan sistem integrasi tanaman jagung-ternak sapi Di Sulawesi Selatan. Prosiding Seminar Insentif Riset Nasional (Insinas 2012): Membangun Sinergi Riset Nasional untuk Kemandirian Teknologi. Bandung 29-30 November 2012. P. 223-228.

Suratman and B.S. Busyra. 2006. Potensi sumberdaya lahan sebagai basis tata ruang pengembangan peternakan ruminansia di Indonesia. Prosiding Seminar Nasional Peternakan - Revitalisasi Potensi Lokal 2006. BPTP Sumbar. P.240-245.

Yani, A and B.P. Purwanto. 2006. Pengaruh iklim mikro terhadap respons fisiologis sapi peranakan Fries Holland dan modifikasi lingkungan untuk meningkatkan produktivitasnya (ULASAN). Media Peternakan. 29(1):35-46.

Yengoh, G.T and M.G.E. Svensson. 2008. Low external input strategies for sustainable small-scale farming in Kenya : A systems dynamic approach. The 26th International Conference of the System Dynamics Society July 20 - 24, 2008 Athens, Greece. P 1-22.

Yusuf, M., A. Fahrudin, C. Kusmana and M.M. Kamal. 2016. Analisis faktor penentu dalam pengelolaan berkelanjutan estuaria DAS Tallo. J. Analisis Kebijakan Kehutanan. 13(1):41-51. 